\title{
Stigmas arrangement, reproductive system, and maternal reproductive success in two species of Stigmaphyllon (Malpighiaceae): does pollinator size matter?
}

\author{
Adan Alberto Avalos (D) Hugo Javier Marrero (D) María Silvia Ferrucci - \\ Juan Pablo Torretta $(1)$
}

Received: 18 May 2021 / Accepted: 27 August 2021

(C) The Author(s), under exclusive licence to Springer Nature B.V. 2021

\begin{abstract}
Most species of Neotropical Malpighiaceae are pollinated by oil-collecting bees of diverse sizes, but the effect of pollinator size on their reproductive success has still not been addressed in the literature. We performed a comparative description of stigma arrangements, analyzing the reproductive system and reproductive success and assessing pollinator sizes in Stigmaphyllon bonariense and Stigmaphyllon jatrophifolium. We collected flowers in three natural populations, conducting pollinator
\end{abstract}

Communicated by Simon Pierce.

Supplementary Information The online version contains supplementary material available at https://doi.org/10.1007/ s11258-021-01176-8.

A. A. Avalos $(\square)$. M. S. Ferrucci

Instituto de Botánica del Nordeste, IBONE-UNNE-

CONICET, Corrientes, Argentina

e-mail: adanalbertoavalos@gmail.com

A. A. Avalos · H. J. Marrero - M. S. Ferrucci .

J. P. Torretta

Consejo Nacional de Investigaciones Científicas y

Técnicas, Buenos Aires, Argentina

H. J. Marrero

Centro de Recursos Naturales Renovables de las Zonas

Semiáridas, CONICET, Bahía Blanca, Argentina

\section{J. P. Torretta}

Facultad de Agronomía, Cátedra de Botánica General, Universidad de Buenos Aires, Av. San Martín 4453,

C1417DSE Buenos Aires, Argentina censuses and captures and performing manipulative experiments to determine the plants breeding system. We analyzed the morphology of stigmas and their receptivity and calculated the perimeter of the triangle formed by the stigmas (ST). Pollinator sizes, potential area for pollen transfer (PAPT), and the frequency of visits were also calculated. Stigma arrangement resulted in inverted triangles, and the ST was smaller in S. jatrophifolium than in S. bonariense. The overlap between ST and PAPT suggests that pollinators of all sizes were efficient in pollinating S. jatrophifolium, whereas only large and very large pollinators where efficient in $S$. bonariense. Moreover, very large pollinators had the highest visit frequencies. Our results indicated that both species are obligate xenogamous, pollinator-dependent, and present pollen limitation. We observed an increase in reproductive success related to the marked turnover in pollinator assemblage throughout the flowering season. These findings suggest that fruit and seed sets vary according to the context of the pollinators and that large pollinators would have the best performance.

Keywords Malpighiales · Pollinator size · Reproductive system $\cdot$ Stigmas $\cdot$ Stigmaphylloid clade 


\section{Introduction}

Angiosperms are characterized by a great diversity of morphologies, function, and postures of stigmas in their flowers (Endress et al. 1983; Endress 1996). This great diversity has long attracted scientists' attention for its implication in plant reproduction (Edlund et al. 2004). Since angiosperm reproduction is highly selective, such variations in stigma traits are expected to be influenced by different selection forces to facilitate ovule fertilization (Edlund et al. 2004). It is known that selective pressures imposed by pollinators play an important role in floral evolution of flowering plants (Stebbins 1970; Schemske and Horvitz 1984; Ollerton 1996; Ollerton and Watts 2000; Harder and Johnson 2009). In this context, an adjustment of the arrangement of floral structures (e.g., gynoecium) to the morphological and/or behavioral traits of pollinators can also be expected to increase the formation of fruits and/or seeds (Johnson and Steiner 2000; Fenster et al. 2004). The size of pollinators is a morphological attribute that can influence the reproductive success of a plant in different ways (Stout 2000; Morais et al. 2020). Hence, evaluating this phenomenon will provide valuable information about the selection force imposed by pollinator size.

The family Malpighiaceae comprises approximately 1300 species distributed in tropical and subtropical regions of the world, with the greatest richness confined to the Neotropics (Davis and Anderson 2010). In this region, most species present a highly specialized pollination system interacting with oilcollecting bees (Anderson 1979; Vogel 1990; Sigrist and Sazima 2004), primarily females of the genera Centris, Epicharis [Apidae: Centridini, following the nomenclature of Michener (2007)], and Monoeca (Apidae: Tapinotaspidini). These solitary bees collect the oil produced by the calyx glands (elaiophores) and use it for larval food provisioning and/or cell lining (Vogel 1974, 1990; Simpson and Neff 1981; Buchmann 1987; Vinson et al. 1996), whereas the flowers of species of Malpighiaceae are effectively pollinated. These flowers present a floral conservatism in terms of attraction, orientation, and reward of pollinators in contrast to a remarkable variety in habit (i.e., subshrubs, shrubs, lianas, and trees) and fruit morphology (i.e., berries, drupes, nutlets, and winged mericarps) (Anderson 1979). Nevertheless, the gynoecium and androecium of these species present considerable variation (Anderson 1979, 1990; Sigrist and Sazima 2004; Aliscioni et al. 2018, 2019; Avalos et al. 2020). Davis et al. (2014) demonstrated that floral stasis in Malpighiaceae is explained by extrinsic factors (e.g., stabilizing selection due to ecological interactions) rather than intrinsic ones (e.g., developmental and genetic constraints). Therefore, flowers of Neotropical Malpighiaceae have their morphology strongly conditioned by the foraging behavior of their pollinators (Anderson 1979; Vogel 1990; Davis et al. 2014).

Regarding the gynoecium, previous contributions demonstrated a high dependence of several species of Malpighiaceae on oil-collecting bees for cuticle breakdown and pollen grain landing on the receptive surface of the stigma (Sigrist and Sazima 2004; Aliscioni et al. 2018). In addition, Aliscioni et al. (2018) correlated the arrangement of stigmas to the size of pollinators (estimated from their intertegular spans, Cane 1987) in Callaeum psilophyllum (A. Juss.) D.M. Johnson. These authors proposed that large pollinators can simultaneously contact the three stigmas in each visit, whereas small ones (e.g., oilcollecting bees of medium size) only contact one or two stigmas. On the other hand, Aliscioni et al. (2019) reported carpel dimorphism in gynoecia of Tricomaria usillo Hook. and Arn. and suggested that it could represent a recent transition toward stable and definitive division of labor of carpels. Thus, it seems evident that gynoecium variations in Malpighiaceae are a good model to analyze the relationship of these species with pollinator traits.

Stigmaphyllon bonariense (Hook. and Arn.) C.E. Anderson and S. jatrophifolium A. Juss. are woody perennial lianas distributed in variable environments in terms of taxonomic diversity and size of pollinators (Torretta et al. 2017). Pollinator assemblage in different populations of both species has shown a pronounced turnover of medium and large to very large species during the flowering season, approximately doubling the size of the pollinators toward the end of the season (Avalos, pers. obs.). According to Ne'eman et al. (2010) the efficiency of a pollinator is based on how much it contributes to reproductive success and for this it is necessary to consider seed set under the given resource constraints of the plant. In addition, different species of pollinators can vary in effective pollen deposition and removal (Schemske and Horvitz 1984; Herrera 1987; Young and Stanton 1990; Wilson 
and Thomson 1991), with large pollinators being expected to have high visitation rates according to their energy requirements (Casey et al. 1985; Harder and Barclay 1994; Mesquita-Neto et al. 2021). In general, the size of a pollinator seems to be a particularly strong determinant of their efficiency (Mesquita-Neto et al. 2021). However, although numerous studies showed that Malpighiaceae species are pollinated by several species of oil-collecting bees (Vogel 1974; Sazima and Sazima 1989; Barros 1992; Sigrist and Sazima 2004; Vilas Boas et al. 2013; Sazan et al. 2014; Torretta et al. 2017; Aliscioni et al. 2018among others), few studies reported any information regarding about differences in pollinator body size (Vilas Boas et al. 2013; Sazan et al. 2014; Barônio and Torezan-Silingardi 2017; Torretta et al. 2017; Aliscioni et al. 2018). Additionally, no study to date has evaluated if pollinator body size effects on fruit and/or seed formation [but see Sazan et al. (2014)].

In this study we addressed an interesting but still unexplored question in Malpighiaceae: is pollinator size related to maternal reproductive success? We hypothesized that maternal reproductive success would be influenced by pollinator size, which in turn determines visitation rates and the contact with the stigmas. Three predictions were tested from this hypothesis: (i) fruit and seed sets will be positively related to size of pollinators; (ii) visitation rates will be positively correlated with pollinator sizes; and (iii) distances among stigmas will be related to the potential area for pollen transfer of large pollinators.

\section{Materials and methods}

Study species and sampling sites

We analyzed S. bonariense and S. jatrophifolium, two woody perennial lianas with yellow flowers, arranged in umbels to corymbs, solitary, or secondarily arranged in dichasia (Múlgura de Romero 2005). Flowers are oblique zygomorphic, with the plane of symmetry passing through the anterior sepal and posterior petal. Calyx 5-merous, the four lateral sepals are glandular and the anterior one is eglandular. Corolla 5-merous with five clawed yellow petals. The posterior petal has a thicker claw than the remaining four lateral petals. Androecium has two pentamerous whorls of heteromorphic stamens and gynoecium is 3-carpellate and 3-locular with one ovule per locule (Avalos et al. 2020).

Natural populations ( $n=3$ for S. bonariense and $n=3$ for $S$. jatrophifolium) were selected from the site El $15\left(27^{\circ} 22^{\prime} \mathrm{S}, 58^{\circ} 41^{\prime} \mathrm{W}\right)$ in Corrientes province (only $S$. bonariense) and different sites of Misiones province: Iguazú National Park $\left(25^{\circ} 40^{\prime} \mathrm{S}, 54^{\circ} 27^{\prime} \mathrm{W}\right.$; both species), Teyú Cuaré Provincial Park $\left(27^{\circ} 17^{\prime} \mathrm{S}\right.$, $55^{\circ} 35^{\prime} \mathrm{W}$, both species), and the locality of San Antonio $\left(26^{\circ} 02^{\prime} \mathrm{S}, 53^{\circ} 51^{\prime} \mathrm{W}\right.$, only $S$. jatrophifolium) (Fig. 1a). The map indicating the studied sites was constructed using SimpleMappr (Shorthouse 2010).

\section{Arrangement of stigmas}

In each sampled population, flowers at pre-anthesis ( $n=60$ to 80 buds of 2-4 mm in length) and anthesis ( $n=100$ flowers, 1-3 days after anthesis) were fixed in formalin, acetic acid, and alcohol (FAA) for further morphological examination. We analyzed the architecture of the flower under stereomicroscope focusing on the arrangement of stigmas. Floral buds were used to observe the position of stigmas at pre-anthesis. In addition, we calculated the perimeter of the triangle formed by stigmas (ST) in superior view in anthetic flowers by measuring the distances between the three stigmas. For this purpose, we analyzed 10 individuals per species in each population, using three flower per individual (in total 90 flowers per species from three populations). The following imaginary lines were drawn among stigmas: "a" between the two posterior stigmas; " $b$ " between right posterior stigma and anterior one; and "c" between left posterior stigma and anterior one (Fig. 1b). Flower morphological analyses and measurement of the distances between stigmas were performed under a Leica MZ6 stereomicroscope, equipped with a digital camera. The voucher specimens (Avalos 4, 16, 35, 38; Torretta 78, 79) were deposited in the herbarium of the Instituto de Botánica del Nordeste (CTES), Argentina.

In addition, we analyzed the stigmatic receptivity of virgin flowers by putting stigmas in contact with an aqueous solution of $40 \%$ hydrogen peroxide. The studied flowers (five flowers per individual, $n=3$ per site) were previously covered with cloth bags and analyzed every $3 \mathrm{~h}$ from buds close to anthesis until flower abscission; the buds were carefully opened using histological forceps. This analysis was compared to the direct observation of the pollen supply 


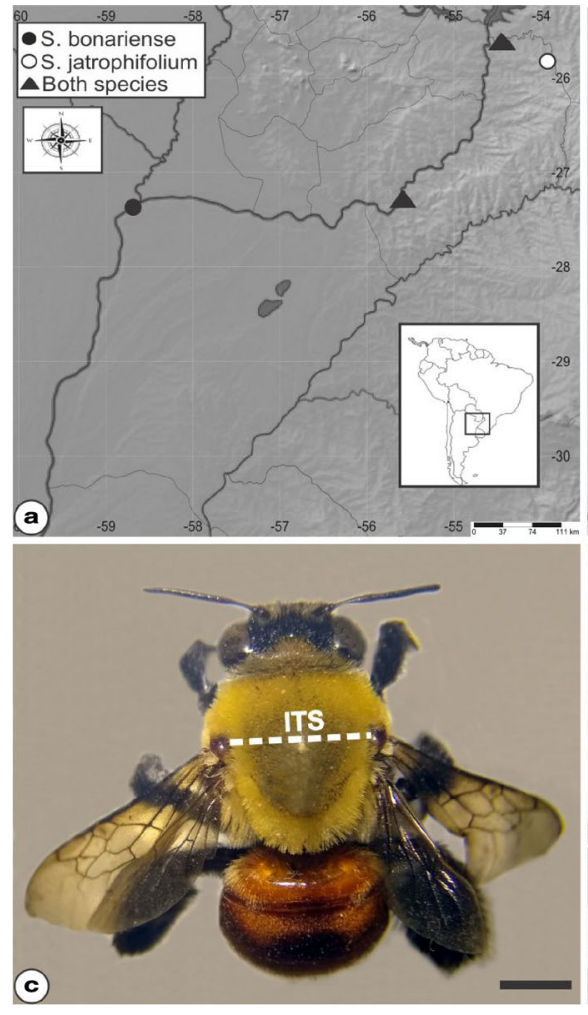

Fig. 1 Distribution map of populations studied and the distances measured in the flowers of Stigmaphyllon species and its pollinators. a Populations studied of $S$. bonariense (black circle), $S$. jatrophifolium (white circle), and both species in the same locality (triangles). b Lines drawn between stigmas to determine the stigmas triangle (ST); "a" between the two posterior stigmas; "b" between right posterior stigma and

from the anthers to determine the presence of dichogamy.

\section{Pollinators and floral visitors}

To distinguish between legitimate pollinators and floral visitors, oil-collecting bees were directly observed on flowers and captured. The species that contacted the reproductive structures (i.e., anthers and/ or stigmas) during foraging activities were recorded as legitimate pollinators, whereas all the foraging insects that did not contact reproductive structures were considered floral visitors. We also estimated frequency of visits (FV) of pollinator bees to flowers by conducting eighty-seven 10-min censuses without capture (58 for $S$. bonariense and 29 for S. jatrophifolium) on a known number of flowers between 7:00 and 19:00 h. These censuses were conducted
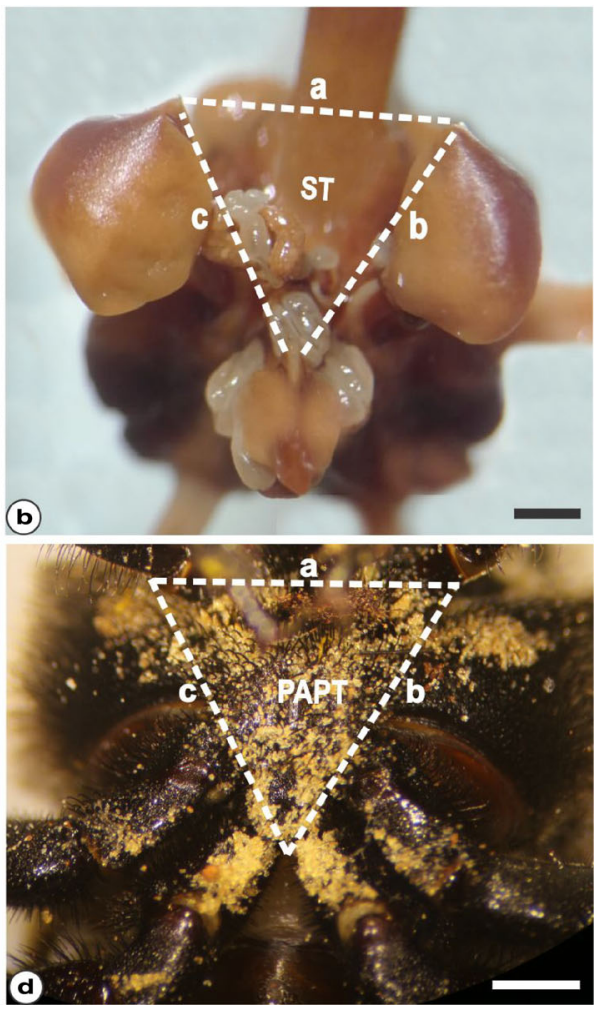

anterior one; and "c" between left posterior stigma and anterior one. $\mathbf{c}$ Intertegular spans (ITS) of a pollinator. $\mathbf{d}$ Lines drawn on the ventral zone of pollinators to delimit the potential area for pollen transfer (PAPT); "a" between posterior procoxal areas, "b" between left posterior procoxal and postmetacoxal area, and "c" between right posterior procoxal and postmetacoxal area. Scale bars $=1 \mathrm{~mm}(\mathbf{b}), 2 \mathrm{~mm}(\mathbf{c}), 1.5 \mathrm{~mm}(\mathbf{d})$

randomly throughout the entire flowering season (i.e., November to May) in all populations. The FV of each species was calculated as number of visits/ (10 min $\times$ number of flowers) and averaged by number of censuses.

Moreover, we captured the oil-collecting bees using entomological nets, placed in a killing jar, mounted with entomological pins, and identified to the lowest taxonomic level possible (i.e., species, genus). Individuals that could not be identified to the species level were assigned to morphospecies.

In the laboratory, pollinators were measured under a stereomicroscope and assigned to size groups according to their intertegular spans (ITS; Fig. 1c) (Cane 1987) in medium (ITS $<4 \mathrm{~mm}$ ), large (ITS 4-6 $\mathrm{mm}$ ) and very large (ITS $>6 \mathrm{~mm}$ ) bees. In addition, digital photographs from the ventral area of the mesosoma were taken $(n=5$ per species or the 
available number in case of species with few individuals). In these photographs, we draw a triangle formed by the following imaginary lines: "a" between posterior procoxal areas, " $b$ " between left posterior procoxal and postmetacoxal area, and "c" between right posterior procoxal and postmetacoxal area (Fig. 1d). Then, we calculated the perimeter of the triangle and used it as proxy for the potential area for pollen transfer (PAPT) of legitimate pollinators of $S$. bonariense $(n=60)$ and $S$. jatrophifolium $(n=28)$. The perimeter of the PAPT triangle was related to the perimeter of the triangle formed by the stigmas (ST) to distinguish the most efficient pollinator (i.e., pollinator that can contact all three stigmas in a single visit) from the least efficient pollinator (i.e., pollinator that cannot contact all three stigmas in a single visit). ST, ITS, and PAPT measurements were taken from digital photographs using the function "length" of ImageJ program (Schneider et al. 2012).

The collected bees were deposited in the Entomological Collection of the Cátedra de Botánica General (FAUBA), Facultad de Agronomía, Universidad de Buenos Aires, Argentina and Entomological Collection of Instituto de Botánica del Nordeste, Corrientes, Argentina.

\section{Breeding system}

We conducted manipulative experiments to determine the breeding system of several individuals of different populations for each plant species during two consecutive flowering periods. The number of individuals used for these experiments was 23 for $S$. bonariense and 17 for $S$. jatrophifolium. In each of them, a known number of floral buds was randomly selected and subjected to the following treatments: (1) openpollination: non-manipulated flowers exposed to free pollination; (2) geitonogamy: virgin flowers bagged with cloth bags and subsequently hand-pollinated using pollen from flowers of the same individual; (3) hand cross-pollination (xenogamy): virgin flowers bagged with cloth bags and subsequently hand-pollinated using a mix of pollen from flowers of several individuals $(n=4-6)$. This experiment also aimed to determine pollen limitation (by comparing fruit set/ mericarp set between open-pollination and hand crosspollination treatments). In geitonogamy and hand cross-pollination treatments, the flowers were bagged at pre-anthesis and once open, they were manually pollinated and re-bagged. For those treatments that required manual pollen deposition, we used a brush to mechanically break the stigma cuticle (see results); (4) anemophily: flowers bagged with 1-mm mesh, excluding floral visitors, and allowing the passage of airborne pollen; and (5) apomixis/spontaneous self-pollination: flowers bagged with cloth bags and untreated. Flowers were not emasculated in any treatment because of spatial separation between anthers and stigmas, caused by apical foliaceous expansion of the stigmas (herkogamy: see results). So, spontaneous contact between anthers and stigmas of the same flower is improbable. This was confirmed because apomixis/ spontaneous self-pollination did not produce fruit (see results). The response variables used to compare treatments were fruit set (formed fruits/treated flowers) and mericarp set (formed mericarps/number of ovules), since these species present schizocarpic fruits and only a single ovule per carpel. Thus, we counted the number of mericarps in the fruits, assuming that a single seed was formed inside. Furthermore, 50 flowers distributed in five individuals of each species were dissected at random to corroborate the number of carpels per flower and ovules per carpel.

According to replacement of pollinators observed during the flowering season (see Results), the manipulative experiments were made considering two different pollinator contexts: (1) without (Wo) and (2) with (W) the presence of very large pollinators. In the first context (Wo), observations of the fruit and seed sets were made in 873 flowers of $S$. bonariense and 741 of $S$. jatrophifolium; in the second context (W), observations were made in 997 flowers of $S$. bonariense and 707 flowers of S. jatrophifolium. To determine the pollinator context in each population, the visits of oil-collecting bees to other co-flowered Malpighiaceae species were also recorded in parallel with censuses on Stigmaphyllon species.

\section{Maternal reproductive success}

Maternal reproductive success of both species was estimated based on the fruit set and mericarp set in the open-pollination treatment in each population. These values were divided by the average of the fruit set and mericarp set (respectively) obtained in the hand crosspollination treatment for each population to make reproductive success comparable among them. 
Statistical analyses

Generalized linear mixed models (GLMMs) were performed to test the different predictions using the "lme4" packages in R statistical program (R Development Core Team 2013; Bates et al. 2018).

(i) Relationship between stigma distances and pollinator sizes A GLMM (function lmer with Gaussian distribution of errors) was performed using the distances between the two posterior stigmas (pp) as response variable. Since we found a correlation among all measured distances (see the section "Arrangement of stigmas" above) we selected only the pp as an indicator of stigma triangle size. Pollinator size and plant species were used as fixed factors and pollinator species was used as a random factor. The model included the interaction between fixed factors (M1, Table S1, SI).

(ii) Visitation rates and pollinator sizes GLMMs (function lmer with Gaussian distribution of errors) were performed with the frequency of pollinator visits (log-transformed) used as response variable. Pollinator size and plant species were used as fixed factors and populations were used as a random factor. Models were selected using the Akaike information criteria (AIC) to estimate which of these factors (or their interaction) best explained the response variable (M2-M4, Table S1, SI).

(iii) Relationships between fruit set, mericarp set and pollinator sizes GLMMs (function glmer with binomial distribution of errors) were performed using fruit set (M5-M6, Table S1) and mericarp set (M7-M8, Table S1) as response variables. Treatment (open-pollination) and pollinator contexts ( $\mathrm{W}$ and $\mathrm{Wo}$ ) were used as fixed factors and population was used as random factor. The models were performed for each species ( $S$. bonariense and $S$. jatrophifolium) separately because the response variables might have opposite effects on each species.

Finally, chi-square values were calculated for each of the models with the Anova function of the "Car" package in $\mathrm{R}$ statistical program (Fox and Weisberg
2019). Tukey contrast tests were carried out for some models (M2, M5-M8; see SI). Tukey's tests were performed using the glht function of the "multcomp" package in R statistical program.

\section{Results}

Gynoecium morphology and stigma arrangement

The gynoecium of both species consists of three carpels, with three free styles that have apical foliaceus expansions (Fig. 2a-h). The two posterior styles show a single apical expansion and are mirror images of each other, whereas the anterior style differs from the posterior ones, showing two apical expansions, one on each side of the style (Fig. 2a-b, d-e, gh). Underneath each apical expansion of the styles there are some "hidden" anthers (Fig. 2b, e-f). Stigmas are located laterally on styles (Fig. 2b-c, f), very close together, and face the interior side of the flower at pre-anthesis stage. On the first day of anthesis, the three styles and their stigmas begin to separate. In $S$. bonariense the two posterior stigmas face the posterior part of the flower, toward the posterior (flag) petal (Fig. 2a, g), whereas in $S$. jatrophifolium those stigmas are oriented to the center of the flower (Fig. 2d, h). However, the anterior stigma presents a similar orientation in both species. We observed the presence of a broken stigmatic cuticle and the receptive surface on stigmas with pollen grains in the flowers exposed to pollinators (Fig. 2c, f). Stigma receptivity and anther dehiscence occurred before petal expansion; therefore, at anthesis both functions were already available and no dichogamy was detected.

In frontal view of the flower, the final arrangement of the stigmas resulted in an inverted triangle (Fig. 2a, d). The formed triangles were scalene in S. bonariense and isosceles in S. jatrophifolium, and the distances between stigmas were $4.07 \pm 0.25 \mathrm{~mm}$ and $1.89 \pm 0.17 \mathrm{~mm}$ (mean $\pm \mathrm{sd}$ ) between the two posterior stigmas, $3.99 \pm 0.24 \mathrm{~mm}$ and $1.91 \pm 0.19 \mathrm{~mm}$ between right posterior stigma and anterior one, and $4.02 \pm 0.21 \mathrm{~mm}$ and $1.89 \pm 0.19 \mathrm{~mm}$ between left posterior and anterior one, respectively (Table 1). 

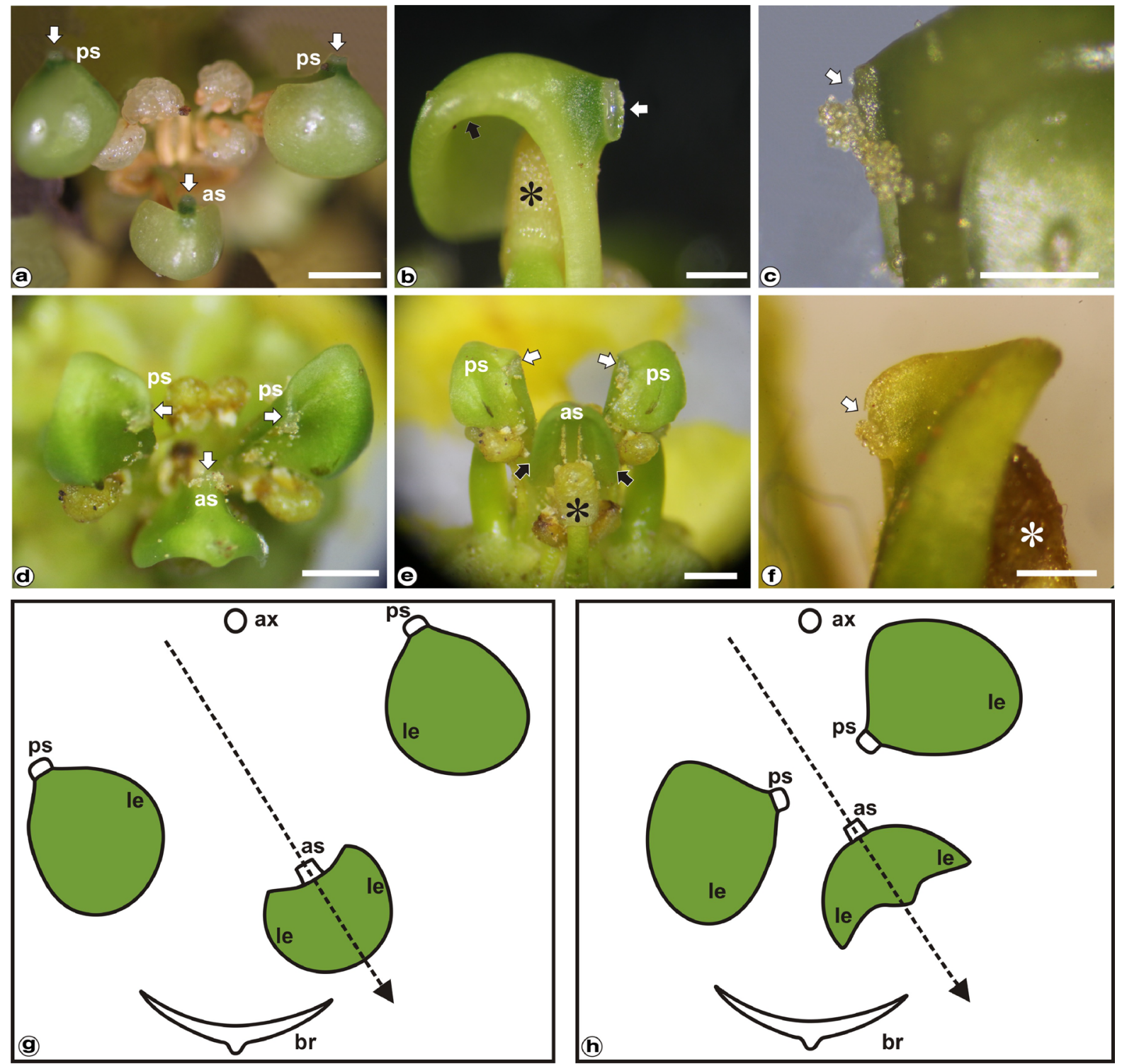

Fig. 2 Arrangement of stigmas in Stigmaphyllon bonariense and $S$. jatrophifolium. a-c $S$. bonariense. a Superior view of the stigmas, note the position of the receptive area (arrows). b Lateral view of a posterior stigma (white arrow) with one lateral expansion of style (black arrow), note the anther "hidden" (asterisk) under the lateral expansion. c Detail of posterior stigma with broken stigmatic cuticle (arrow) and pollen grains over receptive surface. d-f S. jatrophifolium. d Superior view of the stigmas showing the position of the receptive area (arrows). e Anterior view of reproductive structures in flower showing the two posterior stigmas (white arrows), the anterior stigma with two apical expansions (black arrows), and the "hidden" anther (asterisk) below them. f Detail

of posterior stigma with broken stigmatic cuticle (arrow) and pollen grains over receptive surface, note the position of anther (asterisk). $\mathbf{g}$-h Diagram of stigmas in the flower at anthesis; the arrow points to orientation of the monosymmetry in the flower, the position of bract (br), and axis of inflorescence (ax) are represented. $\mathrm{g} S$. bonariense, note that the two posterior stigmas are oriented to posterior part of the flower and the anterior one to the center; all the stigmas are far apart from each other. $\mathbf{h} S$. jatrophifolium, note that all stigmas are oriented to the center of the flower and very close together. as anterior stigma; $a x$ axis of inflorescence; $b r$ bract; le lateral expansion; $p s$ posterior stigma. Scale bars $=1 \mathrm{~mm}(\mathbf{a}, \mathbf{d}, \mathbf{e}), 0.5 \mathrm{~mm}(\mathbf{b}, \mathbf{c}, \mathbf{f})$ 
Table 1 Distances measured among stigmas in flowers of Stigmaphyllon species and the intertegular spans (ITS) and ventral areas of potential pollinator species

\begin{tabular}{|c|c|c|c|c|c|c|}
\hline $\begin{array}{l}\text { Plant species } \\
\text { (n) }\end{array}$ & $\begin{array}{l}\text { Between posterior } \\
\text { stigmas }(\mathrm{mm})\end{array}$ & \multicolumn{2}{|c|}{$\begin{array}{l}\text { Between right posterior stigma and } \\
\text { anterior one }(\mathrm{mm})\end{array}$} & \multicolumn{3}{|c|}{$\begin{array}{l}\text { Between left posterior stigma and } \\
\text { anterior one }(\mathrm{mm})\end{array}$} \\
\hline $\begin{array}{l}\text { S. bonariense } \\
(90)\end{array}$ & $4.07 \pm 0.25$ & $3.99 \pm 0.24$ & & $4.02 \pm 0.21$ & & \\
\hline $\begin{array}{l}\text { S. jatrophifolium } \\
(90)\end{array}$ & $m \quad 1.89 \pm 0.17$ & $1.91 \pm 0.19$ & & $1.89 \pm 0.19$ & & \\
\hline $\begin{array}{l}\text { Pollinator } \\
\text { species } \\
\text { (n) }\end{array}$ & $\begin{array}{l}\text { Posterior } \\
\text { procoxal area } \\
(\mathrm{mm})\end{array}$ & $\begin{array}{l}\text { Between right posterior procoxal } \\
\text { and postmetacoxal areas (mm) }\end{array}$ & $\begin{array}{l}\text { Between lef } \\
\text { and postme }\end{array}$ & $\begin{array}{l}\text { osterior procoxal } \\
\text { oxal areas }(\mathrm{mm})\end{array}$ & $\begin{array}{l}\text { Body } \\
\text { size } \\
\text { ITS } \\
\quad(\mathrm{mm})\end{array}$ & $\begin{array}{l}\text { Captured } \\
\text { over }\end{array}$ \\
\hline $\begin{array}{l}\text { Centris } \\
\quad \text { trigonoides } \\
\text { (10) }\end{array}$ & $1.95 \pm 0.11$ & $2.11 \pm 0.07$ & $2.12 \pm 0.11$ & & $\begin{array}{l}\text { Medium } \\
3.15 \pm \\
0.13\end{array}$ & Both species \\
\hline $\begin{array}{l}\text { Centris } \\
\text { tarsata } \\
\text { (5) }\end{array}$ & $2.46 \pm 0.45$ & $2.37 \pm 0.48$ & $2.40 \pm 0.48$ & & $\begin{array}{l}\text { Medium } \\
3.75 \pm \\
0.09\end{array}$ & S. bonariense \\
\hline $\begin{array}{l}\text { Centris } \\
\text { tricolor } \\
\text { (5) }\end{array}$ & $3.23 \pm 0.14$ & $3.15 \pm 0.15$ & $3.18 \pm 0.19$ & & $\begin{array}{l}\text { Large } \\
4.41 \pm \\
0.14\end{array}$ & S. bonariense \\
\hline $\begin{array}{l}\text { Centris } \\
\text { fuscata } \\
(10)\end{array}$ & $4.67 \pm 0.16$ & $4.73 \pm 0.32$ & $4.66 \pm 0.18$ & & $\begin{array}{l}\text { Large } \\
4.97 \pm \\
0.41\end{array}$ & Both species \\
\hline $\begin{array}{l}\text { Centris } \\
\text { burgdorfi } \\
\text { (1) }\end{array}$ & 4.56 & 4.43 & 4.42 & & $\begin{array}{l}\text { Large } \\
5.00\end{array}$ & S. bonariense \\
\hline $\begin{array}{l}\text { Centris varia } \\
(8)\end{array}$ & $4.57 \pm 0.96$ & $4.52 \pm 0.86$ & $4.43 \pm 0.88$ & & $\begin{array}{l}\text { Large } \\
5.20 \pm \\
1.28\end{array}$ & Both species \\
\hline $\begin{array}{l}\text { Centris } \\
\text { bicolor } \\
\text { (5) }\end{array}$ & $3.97 \pm 0.21$ & $3.98 \pm 0.14$ & $3.98 \pm 0.30$ & & $\begin{array}{l}\text { Large } \\
5.36 \pm \\
0.16\end{array}$ & S. bonariense \\
\hline $\begin{array}{l}\text { Centris } \\
\text { flavifrons }\end{array}$ & $5.24 \pm 0.12$ & $5.20 \pm 0.32$ & $5.19 \pm 0.35$ & & $\begin{array}{l}\text { Very } \\
\text { large }\end{array}$ & S. bonariense \\
\hline (5) & & & & & $\begin{array}{c}6.01 \pm \\
0.05\end{array}$ & \\
\hline $\begin{array}{l}\text { Centris } \\
\text { pectoralis }\end{array}$ & $5.85 \pm 0.26$ & $5.67 \pm 0.39$ & $5.63 \pm 0.38$ & & $\begin{array}{l}\text { Very } \\
\text { large }\end{array}$ & S. bonariense \\
\hline (9) & & & & & $\begin{array}{c}6.87 \pm \\
0.08\end{array}$ & \\
\hline $\begin{array}{l}\text { Centris } \\
\text { sponsa }\end{array}$ & $6.30 \pm 0.25$ & $6.21 \pm 0.23$ & $6.17 \pm 0.23$ & & $\begin{array}{l}\text { Very } \\
\text { large }\end{array}$ & S. bonariense \\
\hline (5) & & & & & $\begin{array}{c}7.04 \pm \\
0.04\end{array}$ & \\
\hline $\begin{array}{l}\text { Epicharis } \\
\text { sp.1 } \\
(10)\end{array}$ & $4.50 \pm 0.23$ & $4.54 \pm 0.22$ & $4.54 \pm 0.14$ & & $\begin{array}{l}\text { Large } \\
5.25 \pm \\
0.15\end{array}$ & Both species \\
\hline
\end{tabular}


Table 1 continued

\begin{tabular}{|c|c|c|c|c|c|}
\hline $\begin{array}{l}\text { Pollinator } \\
\text { species } \\
\text { (n) }\end{array}$ & $\begin{array}{l}\text { Posterior } \\
\text { procoxal area } \\
(\mathrm{mm})\end{array}$ & $\begin{array}{l}\text { Between right posterior procoxal } \\
\text { and postmetacoxal areas }(\mathrm{mm})\end{array}$ & $\begin{array}{l}\text { Between left posterior procoxal } \\
\text { and postmetacoxal areas (mm) }\end{array}$ & $\begin{array}{l}\text { Body } \\
\text { size } \\
\text { ITS } \\
(\mathrm{mm})\end{array}$ & $\begin{array}{l}\text { Captured } \\
\text { over }\end{array}$ \\
\hline $\begin{array}{l}\text { Epicharis } \\
\text { affinis } \\
(10)\end{array}$ & $5.11 \pm 0.10$ & $5.10 \pm 0.17$ & $5.14 \pm 0.14$ & $\begin{array}{l}\text { Large } \\
5.32 \pm \\
0.30\end{array}$ & Both species \\
\hline $\begin{array}{l}\text { Epicharis } \\
\text { sp. } 2\end{array}$ & $5.51 \pm 0.24$ & $5.28 \pm 0.32$ & $5.24 \pm 0.30$ & $\begin{array}{l}\text { Very } \\
\text { large }\end{array}$ & Both species \\
\hline (10) & & & & $\begin{array}{c}6.12 \pm \\
0.08\end{array}$ & \\
\hline
\end{tabular}

\section{Pollinators and floral visitors}

In the analyzed populations, we captured 10 species of Centris and three of Epicharis from both Stigmaphyllon species (Table 1). All these bees legitimately visited the flowers while they were oil harvesting. The pollinator oriented the head to the flag petal, grasped the claw of this petal with its mandibles, and scraped the elaiophores of lateral sepals with fore- and middle legs, while the ventral part of the thorax contacted the reproductive structures of flowers (Fig. 3a-c). According to their ITS, the species Centris tarsata and $C$. trigonoides were grouped as medium-sized pollinators; C. bicolor, C. burgdorfi, C. fuscata, C. tricolor, C. varia, Epicharis affinis, and E. sp. 1 as large pollinators; and C. flavifrons, $C$. obsoleta, $C$. cf. sponsa and $E$. sp. 2 as very large pollinators (Table 1). Moreover, we captured several species of Tetrapedia (Tetrapediini) and Paratetrapedia (Tapinotaspidini) that illegitimately visited Stigmaphyllon flowers.

The potential area for pollen transfer (PAPT) varied among pollinator species (Table 1). Likewise, the species studied here differed in the distances between the two posterior stigmas (pp), so the triangle formed by the stigmas (ST) varied between Stigmaphyllon species (Table 1), with ST in S. jatrophifolium being smaller than in S. bonariense (Chisq $=4364.8696$, $p$ value $<0.0001)$. However, there was no relationship between pp and pollinator size (Chisq $=0.0057$, $p$ value $=0.9399)$. The overlap between PAPT and ST indicates that medium-sized, large, and very large species were efficient pollinators for S. jatrophifolium, whereas for S. bonariense only the large and very large pollinators were the most efficient (Fig. 3d-f).

Moreover, we observed a marked replacement in taxonomic composition and in size of pollinators during the flowering season of both species. Initially, pollinators were medium-sized and large (Fig. 4) and as flowering progressed, they were replaced by very large species (Fig. 4). In addition, very large pollinators showed higher frequency of floral visits than smaller ones (large and medium) (Chisq $=30.136$, $p$ value $=2.858 \mathrm{e}-07$ ). On average, very large pollinators made almost a twofold number of visits with respect to the remaining pollinators (Fig. 5). The model that only included pollinator size was the one with the best fit $[\mathrm{M} 2=\operatorname{lmer}($ visit $\sim(1$ lsite $)+$ size, Gaussian distribution), Table S1].

Breeding system and maternal reproductive success

Fruit and mericarp sets varied among treatments. The Hand cross-pollination (HCP) treatment resulted in a higher number of fruits and mericarps, followed by Open-pollination (OP) (Fig. 6a-d). The other treatments (geitonogamy, anemophily, and apomixis/selfpollination) did not produce fruits or produced fruits in very low proportions.

Hand cross-pollination and open-pollination showed significant differences between them, and each of them differed between pollinator contexts (without and with very large pollinators) (Fig. 6a-d). Thus, the maternal reproductive success of $S$. bonariense showed significant differences in fruit (Chisq $=$ 

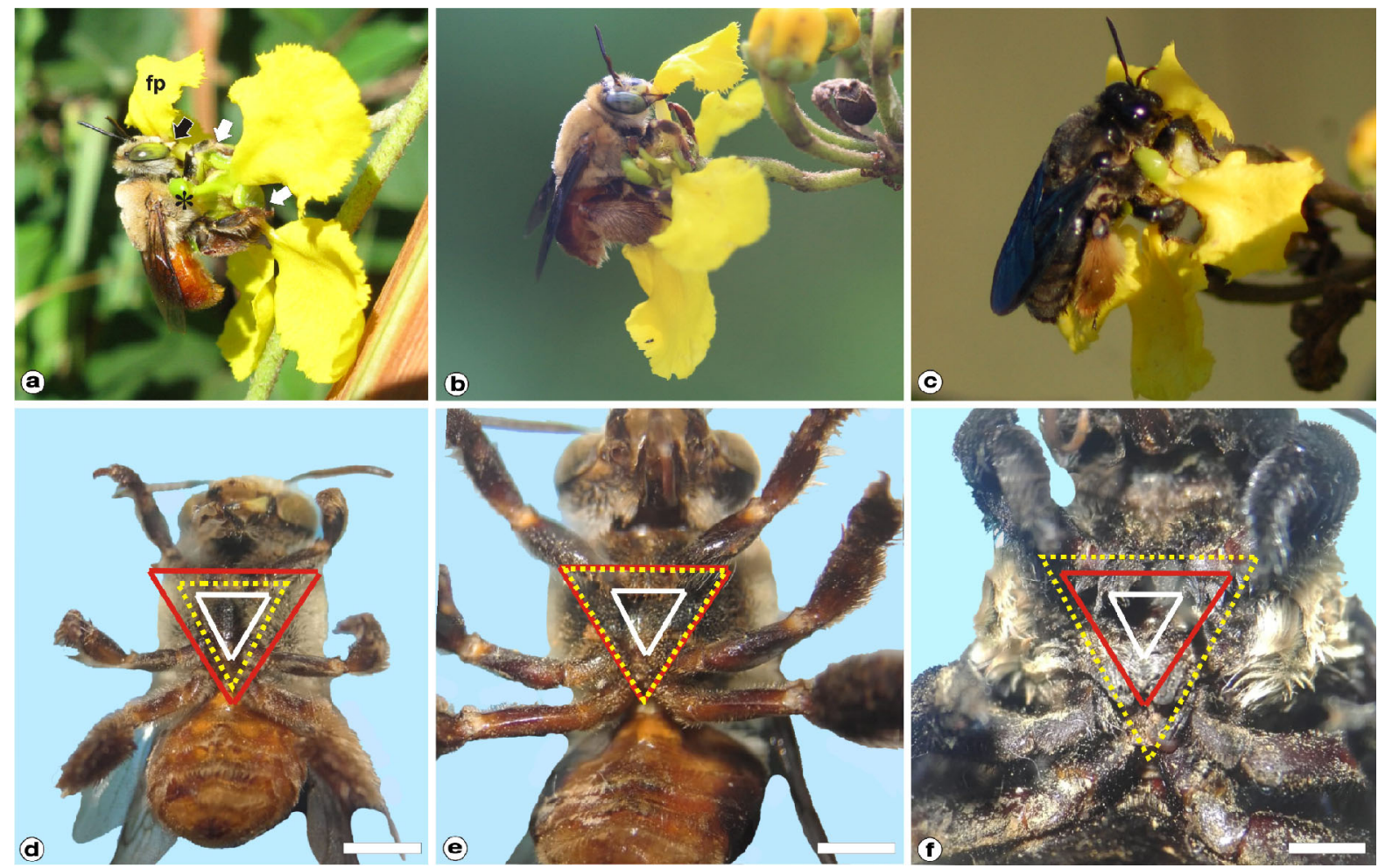

Fig. 3 Pollinators of different body size and overlap between the potential area for pollen transfer (PAPT) of pollinators and stigmas triangle (ST) of Stigmaphyllon species. a-c Pollinators visiting $S$. bonariense flowers. a Medium-sized pollinator, Centris trigonoides, performing its stereotyped visit on a $S$. bonariense flower. Note that its mandibles grasp the flag petal claw (black arrow), legs I and II scrape the elaiophores (white arrows), and the ventral part of the mesosoma contacts with

41.101, $p$ value $=1.445 \mathrm{e}-10$; Fig. 6a) and mericarp $($ Chisq $=143.029, p$ value $<2.2 \mathrm{e}-16$; Fig. $6 \mathrm{~b})$ sets, being higher in the presence of very large pollinators for the OP treatment. However, the fruit set for HCP treatment showed a slight but significant decrease in the latter pollinator context (Fig. 6a). On the contrary, in $S$. jatrophifolium only fruit set showed significant differences $\quad($ Chisq $=22.756, p$ value $=1.840 \mathrm{e}-6$; Fig. 6c) between pollinator contexts for OP treatment, being higher in the presence of very large pollinators. Mericarp set did not show significant differences either between treatments or between pollinator contexts $($ Chisq $=0.6138, p$ value $=0.43338$; Fig. $6 d$ ) . Furthermore, we observed no differences in fruit and/ or mericarp sets among populations for either species. Outputs and specifications of all models are shown in the Supplementary Information (Table S2). reproductive structures (asterisk). b Large-sized pollinator ( $C$. fuscata). c Very large-sized pollinator (Epicharis sp. 2). df Pollinators of different body sizes with the ST of both Stigmaphyllon species represented. Note that the PAPT (yellowdotted line) and ST of $S$. bonariense (red triangle) and $S$. jatrophifolium (white triangle) are represented. d Medium-sized pollinator. e Large-sized pollinator. f Very large-sized pollinator. $f p$ flag petal. Scale bars $=2 \mathrm{~mm}(\mathbf{d}-\mathbf{f})$

\section{Discussion}

Stigmas arrangement of both Stigmaphyllon species showed a remarkable morphological variation, mainly in relation to the position of the posterior stigmas: in $S$. bonariense, they were oriented toward the posterior (flag) petal, whereas in S. jatrophifolium they were facing the center of flower. This difference in the location of posterior stigmas produces functional discrepancies associated with the size of the triangle formed by stigmas (ST) in each species. This finding suggests that $S$. bonariense requires pollinators of adequate size to contact all the stigmas in a single visit and thus improves pollination, as previously proposed for Callaeum psilophyllum (Aliscioni et al. 2018). Two conditions would exacerbate this fact: (1) high availability of pollen at the "vertices" of the ST [i.e., position of anthers with high quantity of pollen, see 


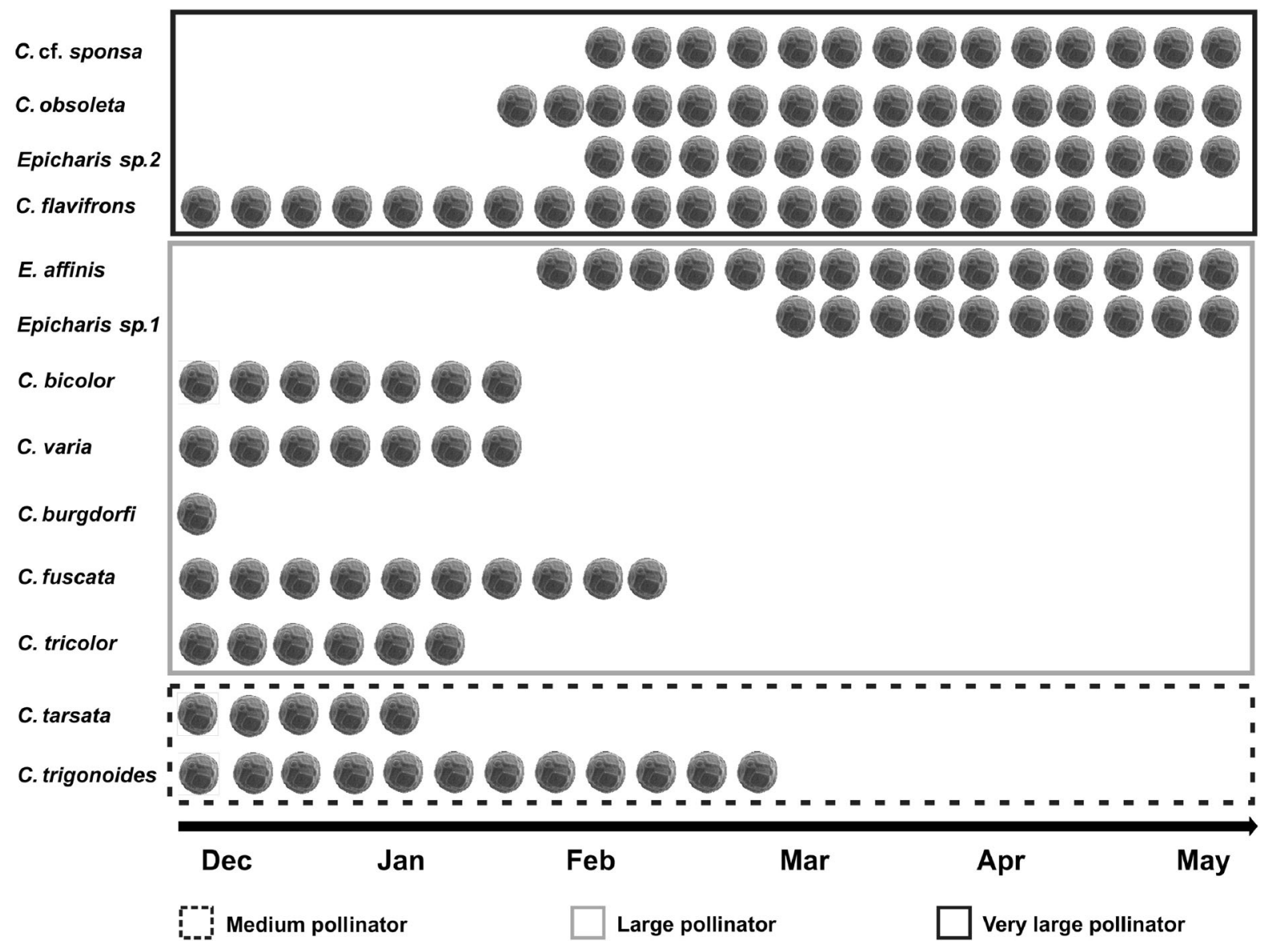

Fig. 4 Replacement of pollinators throughout flowering season in studied populations. The pollinator species are represented on the vertical axis (from smallest to largest body size) and the months (December to May) on the horizontal one. The pollen grains represent the times when each pollinator was captured

during the flowering season of one or both species of Stigmaphyllon. The boxes group the pollinators according to their body size: medium (dotted-line box), large (gray box), and very large (black box)

Avalos et al. (2020)]; and (2) presence of a stigmatic cuticle that must be broken down by pollinators for pollen grains to reach the stigmatic receptive surface (Sigrist and Sazima 2004; Aliscioni et al. 2018, 2019). Thus, if pollinators do not contact all the vertices of the triangle, they cannot break all stigmatic cuticles and deposit pollen grains on the three stigmas to make pollination effective.

Regarding legitimate pollinators, we recorded a wide range of body sizes and their potential areas for PAPT. Potts et al. (2001) observed that large native bees were generally more efficient at delivering pollen grains to the receptive stigmas than smaller ones in Satureja thymbra L. (Lamiaceae). Therefore, our data about pollinator body size and their PAPT suggest a differential ability of different oil-collecting bees to

deposit pollen grains. We also recorded a marked turnover in the pollinator assemblage (composition and size) throughout the flowering season for both Stigmaphyllon species. Temporal variation in pollinator assemblage is a common factor affecting plant fitness (Herrera 1988; Traveset and Sáez 1997; Potts et al. 2001). Therefore, a differential reproductive success related to variation in pollinator context would be expected throughout the flowering season of both Stigmaphyllon species.

Regarding the breeding system, our results indicate that the studied populations of both Stigmaphyllon species: (1) are obligate xenogamous due to selfincompatibility; (2) are pollinator-dependent; and (3) present pollen limitation. According to the studies conducted to date, self-compatibility seems to be 


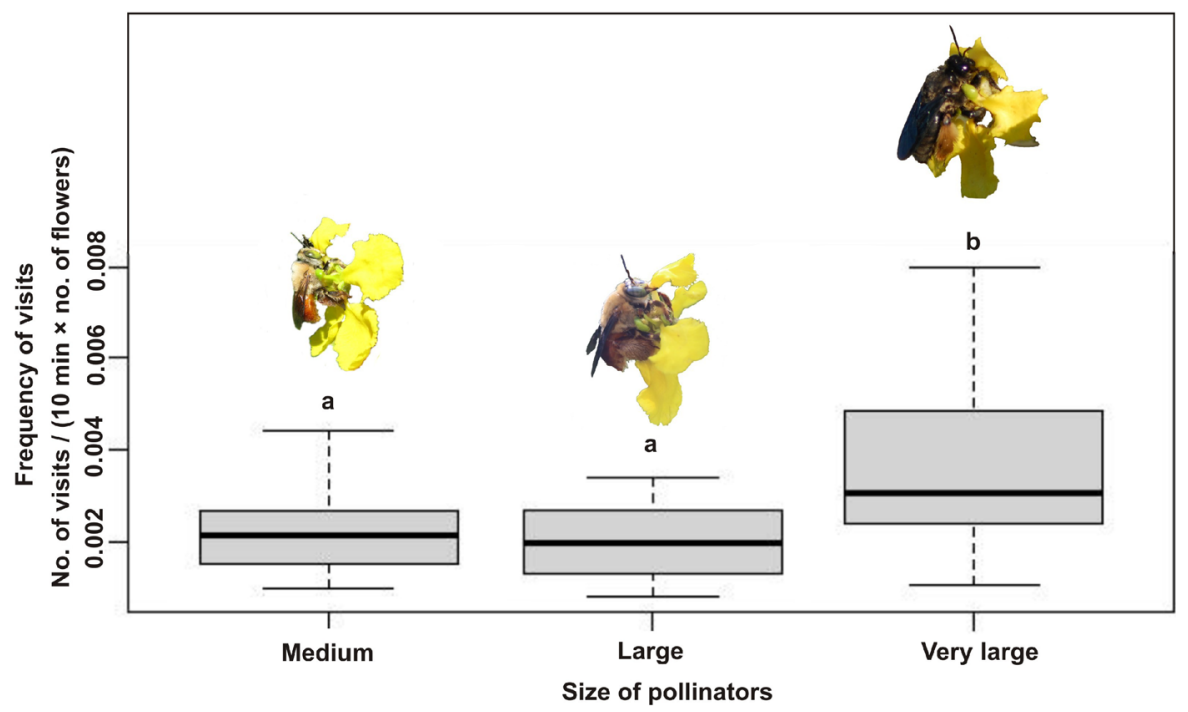

Fig. 5 Frequency of visits between different sizes of pollinator (medium, large, and very large) of both Stigmaphyllon species. Different letters indicate statistically significant differences $(P \leq 0.05)$

common among Neotropical Malpighiaceae, with some strategies like herkogamy, protogyny, and the presence of thick stigmatic cuticle to reduce and/or avoid self-pollination (Sigrist and Sazima 2004). From ca. 90 Neotropical species of Stigmaphyllon (Anderson 1997), the reproductive system has been reported in only two of them: self-incompatibility for $S$. lalandianum A. Juss. (Sigrist and Sazima 2004) and self-compatibility for $S$. paralias A. Juss. (Costa et al. 2006). In both studied species here, the main strategy to escape self-fertilization is self-incompatibility. However, the apical expansions of styles that spatially separate the anthers from the stigmas (i.e., herkogamy) can also help to avoid pollen-stigma interference within flowers. This fact would be particularly important since no dichogamy was detected. Nevertheless, a gynomonoecious sexual system has also been proposed to reduce self-pollination in the same populations of $S$. bonariense analyzed in this study (Avalos et al. 2020).

Pollinator dependence has been largely recorded in Malpighiaceae, mainly due to the stigmatic cuticle needing mechanical rupture by the oil-collecting bees (Sigrist and Sazima 2004; Aliscioni et al. 2018, 2019). In our focal species we observed a rupture of the stigma cuticle in legitimately visited flowers in openpollination. Bees cause mechanical rupture of the cuticle, allowing pollen to adhere to the stigmatic surface and hydrate, an essential requirement for germination (Heslop-Harrison and Heslop-Harrison 1985). Pollinator dependence due to this trait seems to be widespread in Malpighiaceae and could promote the emergence and maintenance of additional functions provided by pollinators. Avalos et al. (2020) suggested that pollinators could cause a similar mechanical rupture of the connective glands in heterantherous Stigmaphyllon species. Moreover, in our focal species, self-incompatibility forces xenogamy for fruit and seed formation and increases pollinator dependence to achieve pollen delivery among individuals.

Pollen limitation is known to affect plant reproduction both in terms of pollen quantity and quality (Ashman et al. 2004). The negative influence of any of these aspects would reduce fruit or seed (mericarp) sets, as we observed for both Stigmaphyllon species. An evolutionary argument regarding the diversity of plant reproductive strategies has been that plants evolve to reduce pollen limitation, and a reduction in reliance on pollinators is expected (Lloyd 1974; Lloyd and Schoen 1992), contrarily to our findings in both Stigmaphyllon species. However, different authors have questioned the evolution toward reduction of pollinator dependence based on the lack of critical research focusing on the interface between the ecological and evolutionary consequences of pollen limitation (Ashman et al. 2004). 


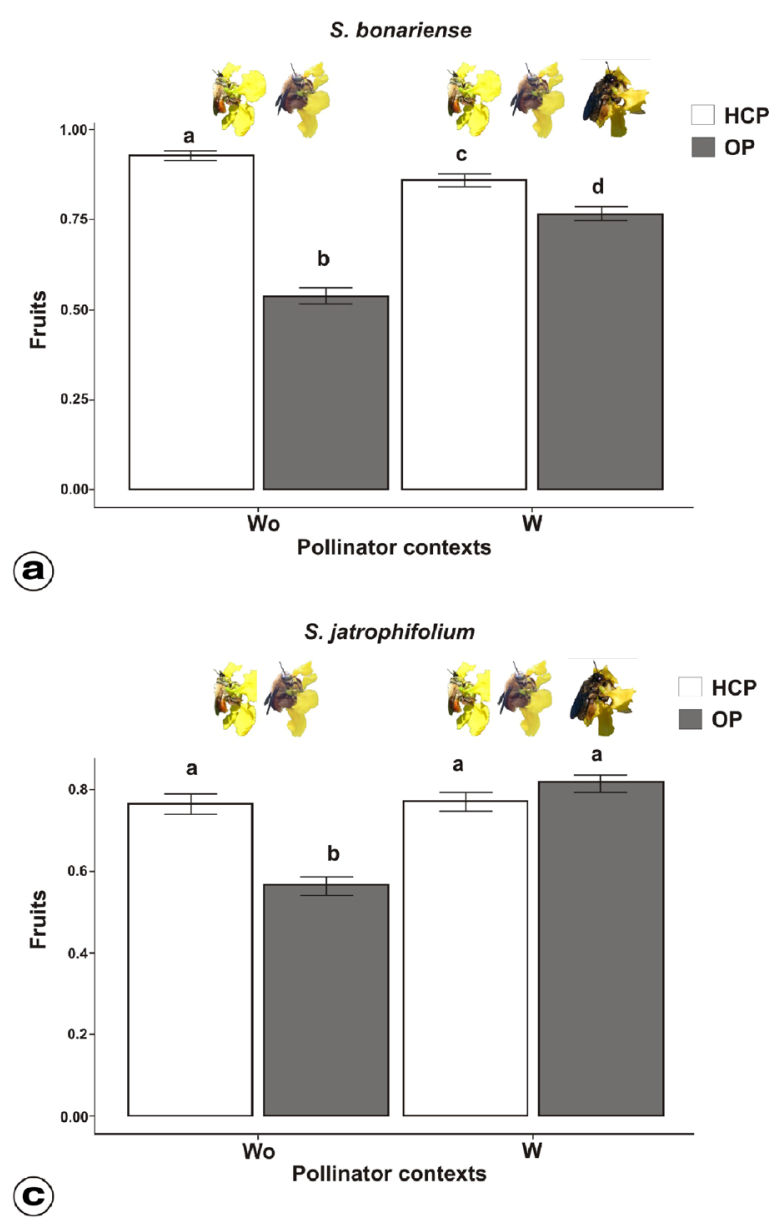

Fig. 6 Fruits set and mericarps set for Hand cross-pollination (HCP) and Open-pollination (OP) treatments in both Stigmaphyllon species. a Fruits set in $S$. bonariense. b Mericarps set in $S$. bonariense. c Fruits set in S. jatrophifolium. d Mericarps set in

Does pollinator size matter?

Our results showed that maternal reproductive success of both Stigmaphyllon species for open-pollination increased in the presence of very large bees, with pollen limitation being low in this pollinator context. In $S$. bonariense, maternal reproductive success increases due to increasing fruit and mericarp sets, whereas in $S$. jatrophifolium it only increases due to increasing fruit set. However, the fact that in $S$. bonariense the fruit set obtained in hand crosspollination treatment decreased could be due to: (a) differences in environmental conditions (e.g., variations in rainfall) at this flowering time; and/or (b) resource limitation, because in open-pollination

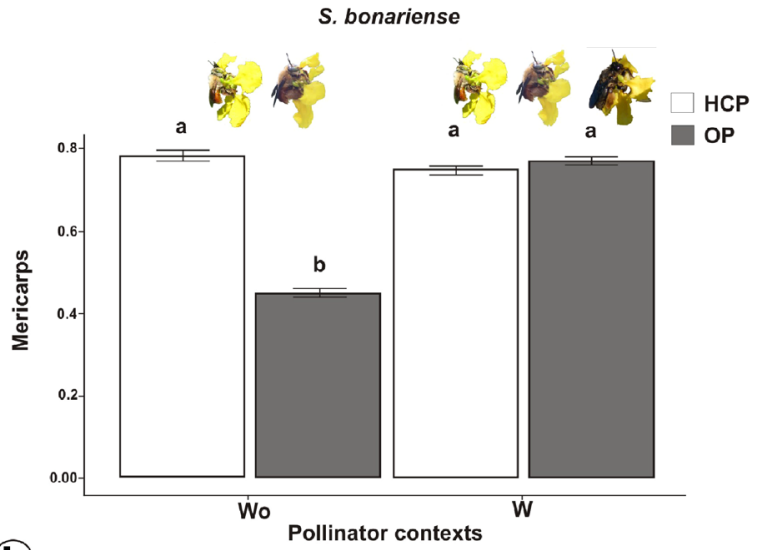

(b)

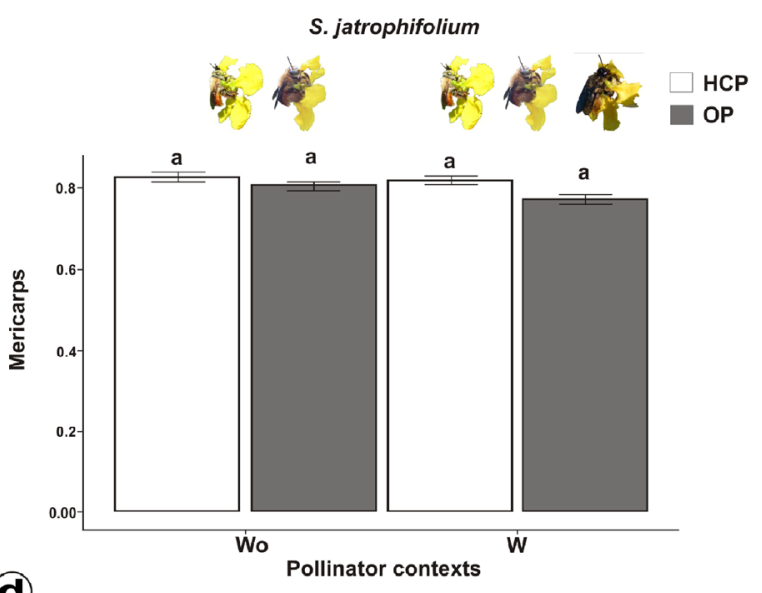

S. jatrophifolium. Two pollinator contexts were considered for each treatment: without (Wo) and with (W) the presence of very large pollinators. Different letters indicate statistically significant differences $(P \leq 0.05)$

the fruit set increases and more energy is required for fruit development. These results confirm our first prediction for $S$. bonariense and partially for $S$. jatrophifolium. On the other hand, the maternal reproductive success showed no differences among the populations analyzed in this study, which could be explained by similarity in terms of size and replacement of the oil-collecting bees present in these populations (Roig Alsina 2000; Moure et al. 2007; Torretta et al. 2017).

Moreover, we observed that pollinator efficiency varied with body size, with direct effects on fruit and/ or mericarp sets. Very large pollinators had higher visitation rates than medium-sized and large ones, which support our second prediction. On the other 
hand, the overlap between PAPT and ST showed differences between plant species. The ST of $S$. jatrophifolium can come into contact with the PAPT of pollinators of all sizes, but the ST of S. bonariense can only meet the PAPT of large and very large pollinators. Contrarily to our expectation, these results partially support our third prediction (only for $S$. bonariense). In addition to properly contacting floral reproductive organs, large oil-collecting bees in Malpighiaceae are also known to be efficient pollinators due to other behavioral traits (Sigrist and Sazima 2004; Barônio and Torezan-Silingardi 2017; Barônio et al. 2020; Mesquita-Neto et al. 2021). For example, large bees can visit more plants per minute (MesquitaNeto et al. 2021) and/or visit more flowers and spend less time per visit in comparison to smaller bee species (Barônio and Torezan-Silingardi 2017; Barônio et al. 2020). However, the latter will depend on the amount and type of reward harvested (e.g., oil or pollen) from the flowers (Barônio et al. 2020).

According to these findings, the increase of maternal reproductive success due to higher fruit set in the context of very large pollinators (W) would be mainly explained by higher frequency of visits in both Stigmaphyllon species. Likewise, in S. bonariense the increase in maternal reproductive success due to higher mericarp set in the second context of pollinators (W) would be mainly explained by the contact of three stigmas per visit performed by larger pollinators. Consequently, the maternal reproductive success of $S$. bonariense would be influenced by higher frequency of visits and an adequate PAPT of larger pollinators to reach all stigmas, whereas in $S$. jatrophifolium it would only be affected by a higher frequency of visits because the ST is so small that pollinators of any size can reach all three receptive areas on each visit. Almeida and Mamede (2016) conducted fieldwork and analysis of herbarium collections of 19 species of Stigmaphyllon from the Atlantic rainforest. Of them, 10 species exhibit a similar condition to $S$. jatrophifolium with respect to position of the posterior stigmas, whereas other eight species show similitude with $S$. bonariense, and only a single species (S. lanceolatum C.E. Anderson) presents a specific state in which the posterior stigmas are oriented toward the anterior-lateral petals. Therefore, the species with a condition similar to that of $S$. bonariense would be expected to have high dependence for large-sized bees to maximize their reproductive success, since these bees would be needed to increase mericarps (and seeds) formation. When this situation is considered from an ecological perspective, reproductive strategies locally adapted to the sizes of pollinators in each population would be expected. For example, if there are no large or very large bee species (or their abundance is low with respect to medium-sized species) in a particular population [e.g., southern limit of the distributions of our focal species (Torretta et al. 2017)], Stigmaphyllon species with large ST should require local adaptations to increase their reproductive success.

So far, we have focused our discussion on very large bees' morphological and behavioral traits that could play a role in increasing maternal reproductive success when pollinator assemblage turnover occurs. However, a positive result of reproductive success is also expected if the replaced oil-collecting bees (mainly medium-sized ones) are less efficient pollinators compared to the "new" very large bees. Therefore, we propose another plausible explanation, which was not confirmed in this study, to our results about the differential maternal reproductive success between pollinator contexts. It is known that gene flow by pollen is determined mainly by flight patterns of pollinators (Handel 1983; Collevatti et al. 2000) and that foraging distance increases with bee body size (i.e., larger bees forage disproportionately farther than smaller ones) (Greenleaf et al. 2007). Therefore, the long-distance cross-pollination between individuals of a population improves the reproductive success of plant species (Hirao 2010; Sazan et al. 2014). Accordingly, medium-sized oil-collecting bees might deposit less genetically variable pollen or more selfpollen (i.e., might increase geitonogamy) on stigmas due to their shorter foraging distance, and this would also decrease the fruit and/or seed sets. Contrarily, larger oil-collecting bees can transport pollen between distant individuals, with less genetic relatedness among parents, as was reported in Byrsonima cydoniifolia A. Juss. [Malpighiaceae, Sazan et al. (2014)]. Thus, in self-incompatible plants like our focal species, the larger pollinators pollinate more flowers (higher visit rate) and more efficiently (they contact all three stigmas in one visit) and could be contributing to greater genetic variability in the population (transporting more genetically variable pollen). This explanation does not rule out the other main ones we proposed. 


\section{Conclusion}

The data generated here fill a significant gap in the understanding of the effect of bee size on maternal reproductive success in two species of the Neotropical Malpighiaceae. This study highlights the relationship between pollinator body size and potential area for pollen transfer (PAPT) in the delivery of pollen grains among different oil-collecting bees in two Stigmaphyllon species. The relationship was evidenced by the increase in fruits and/or mericarps set in the presence of larger pollinators observed during a marked turnover in pollinator assemblage (from smaller to larger bees) throughout the flowering season. The main reasons explaining the increase in maternal reproductive success would be higher frequency of visits and an adequate PAPT of larger pollinators to reach all three receptive areas in $S$. bonariense. Nevertheless, in $S$. jatrophifolium it would only be explained by a higher frequency of visits, since triangle of stigmas is small enough for pollinators of any size to reach all stigmas on each visit. Thus, these findings suggest that fruit and/or seed set vary according to the context of the pollinators and that large pollinators are the most efficient at pollinating the flowers of these species. Further studies should test the hypothesis of flying distances by analyzing the genetic variability of seeds formed in both pollinator contexts to assess whether gene flow varies throughout the flowering season of these Stigmaphyllon species.

Acknowledgements We thank N.A. Ramirez for helping with the statistical figures. To the Administración de Parque Nacionales (Regional NEA) and Ministerio de Ecología y Recursos Naturales Renovables, province of Misiones for the permission to conduct part of this study in protected areas of Argentina. The manuscript benefited from critical reading by R.F. de Almeida and one anonymous reviewer. Consejo Nacional de Investigaciones Científicas y Técnicas (PIP 11220170100429C), Argentina and the Universidad de Buenos Aires (UBACyT 20020130200203BA) for the financial support for this research.

Author contributions All authors contributed to the study conception and design. Material preparation, data collection, and analysis were performed by AAA. The first draft of the manuscript was written by AAA and all authors commented on previous versions of the manuscript. The statistical analyses were carried out by HJM. All authors read and approved the final manuscript.

Funding Financial support for this research was provided by the Consejo Nacional de Investigaciones Científicas y Técnicas
(PIP 11220170100429C), Argentina and the Universidad de Buenos Aires (UBACyT 20020130200203BA).

\section{Declarations}

Conflicts of interest The authors declare that they have no conflict of interest.

\section{References}

Aliscioni SS, Gotelli M, Torretta JP (2018) Structure of the stigma and style of Callaeum psilophyllum (Malpighiaceae) and its relation with potential pollinators. Protoplasma 255:1433-1442. https://doi.org/10.1007/s00709018-1245-x

Aliscioni SS, Gotelli M, Torretta JP (2019) Gynoecium with carpel dimorphism in Tricomaria usillo, comparison with other genera of the Carolus clade (Malpighiaceae). Protoplasma 256:1133-1144. https://doi.org/10.1007/s00709019-01373-3

Almeida RFD, Mamede MCH (2016) Sinopse de Malpighiaceae no Estado do Espírito Santo, Brasil: Stigmaphyllon A. Juss Hoehnea 43:601-633. https://doi.org/10.1590/2236-890622/2016

Anderson WR (1979) Floral conservatism in neotropical Malpighiaceae. Biotropica 11:219-223

Anderson WR (1990) The origin of the Malpighiaceae-The evidence from morphology. Mem N Y Bot Gard 64:210-224

Anderson CE (1997) Monograph of Stigmaphyllon (Malpighiaceae). University of Michigan Herbarium

Ashman T-L et al (2004) Pollen limitation of plant reproduction: ecological and evolutionary causes and consequences. Ecology 85:2408-2421. https://doi.org/10.1890/03-8024

Avalos AA, Torretta JP, Lattar EC, Ferrucci MS (2020) Structure and development of anthers and connective glands in two species of Stigmaphyllon (Malpighiaceae): are heteromorphic anthers related to division of labour? Protoplasma 257:1165-1181. https://doi.org/10.1007/s00709020-01497-x

Barônio GJ, Torezan-Silingardi HM (2017) Temporal niche overlap and distinct bee ability to collect floral resources on three species of Brazilian Malpighiaceae. Apidologie 48:168-180. https://doi.org/10.1007/s13592-016-0462-6

Barônio GJ, de Brito VLG, Nogueira A, Rech AR (2020) Beyond robbery: the role of upside-down behaviour performed by small oil-collecting bees in Malpighiaceae. Arthropod Plant Interact 14:613-621. https://doi.org/10. 1007/s11829-020-09770-9

Barros MAG (1992) Fenologia da floração, estrategias reproductivas e polinização de espécies simpátricas do gênero Byrsonima Rich. (Malpighiaceae). Rev Bras Biol 52:343

Bates D, Maechler M, Bolker B, Walker S, Christensen RHB, Singmann H, Dai B, Scheipl F, Green P (2018) Package 'Ime4'. Version, 1,17. CRAN. R Foundation for Statistical Computing, Vienna, Austria 
Buchmann SL (1987) The ecology of oil flowers and their bees. Annu Rev Ecol Syst 18:343-369. https://doi.org/10.1146/ annurev.es.18.110187.002015

Cane JH (1987) Estimation of bee size using intertegular span (Apoidea). J Kans Entomol Soc 1:145-147

Casey TM, May ML, Morgan KR (1985) Flight energetics of euglossine bees in relation to morphology and wing stroke frequency. J Exp Biol 116:271-289

Collevatti RG, Schoereder JH, Campos LAO (2000) Foraging behavior of bee pollinators on the tropical weed Triumfetta semitriloba: flight distance and directionality. Rev Bras Biol 60:29-37. https://doi.org/10.1590/S003471082000000100005

Costa CBN, Costa JAS, Ramalho M (2006) Biologia reprodutiva de espécies simpátricas de Malpighiaceae em dunas costeiras da Bahia, Brasil. Braz J Bot 29:103-114. https:// doi.org/10.1590/S0100-84042006000100010

Davis CC, Anderson WR (2010) A complete generic phylogeny of Malpighiaceae inferred from nucleotide sequence data and morphology. Am J Bot 97:2031-2048. https://doi.org/ 10.3732/ajb.1000146

Davis CC, Schaefer H, Xi Z, Baum DA, Donoghue MJ, Harmon LJ (2014) Long-term morphological stasis maintained by a plant-pollinator mutualism. Proc Natl Acad Sci 111:5914-5919. https://doi.org/10.1073/pnas.1403157111

Edlund AF, Swanson R, Preuss D (2004) Pollen and stigma structure and function: the role of diversity in pollination. Plant Cell 16:S84-S97. https://doi.org/10.1105/tpc.015800

Endress PK (1996) Diversity and evolutionary biology of tropical flowers. Cambridge University Press, Cambridge

Endress PK, Jenny M, Fallen ME (1983) Convergent elaboration of apocarpous gynoecia in higher advanced dicotyledons (Sapindales, Malvales, Gentianales). Nord J Bot 3:293-300. https://doi.org/10.1111/j.1756-1051.1983. tb01941.x

Fenster CB, Armbruster WS, Wilson P, Dudash MR, Thomson JD (2004) Pollination syndromes and floral specialization. Annu Rev Ecol Evol Syst 35:375-403. https://doi.org/10. 1146/annurev.ecolsys.34.011802.132347

Fox J, Weisberg S (2019) An R companion to applied regression, 3rd edn. Sage, Thousand Oaks

Greenleaf SS, Williams NM, Winfree R, Kremen C (2007) Bee foraging ranges and their relationship to body size. Oecologia 153:589-596. https://doi.org/10.1007/s00442007-0752-9

Handel SN (1983) Pollination ecology, plant population structure, and gene flow. Pollination Biology 163:211

Harder LD, Barclay RMR (1994) The functional significance of poricidal anthers and buzz pollination: controlled pollen removal from Dodecatheon. Funct Ecol 8:509-517. https:// doi.org/10.2307/2390076

Harder LD, Johnson SD (2009) Darwin's beautiful contrivances: evolutionary and functional evidence for floral adaptation. New Phytol 183:530-545. https://doi.org/10. 1111/j.1469-8137.2009.02914.x

Herrera CM (1987) Gene flow components in Lavandula latifolia Medicus: pollination and seed dispersal. Ann Jard Bot Madrid 44:49-61

Herrera CM (1988) Variation in mutualisms: the spatiotemporal mosaic of a pollinator assemblage. Biol J Linn Soc
35:95-125. https://doi.org/10.1111/j.1095-8312.1988. tb00461.x

Heslop-Harrison J, Heslop-Harrison Y (1985) Surfaces and secretions in the pollen-stigma interaction: a brief review. J Cell Sci 1985:287-300. https://doi.org/10.1242/jcs.1985. Supplement_2.15

Hirao AS (2010) Kinship between parents reduces offspring fitness in a natural population of Rhododendron brachycarpum. Ann Bot 105:637-646. https://doi.org/10.1093/ aob/mcq018

Johnson SD, Steiner KE (2000) Generalization versus specialization in plant pollinator systems. Trends Ecol Evol 15:140-144. https://doi.org/10.1016/S01695347(99)01811-X

Lloyd DG (1974) Theoretical sex ratios of dioecious and gynodioecious angiosperms. Heredity 32:11-34. https://doi. org/10.1038/hdy.1974.2

Lloyd DG, Schoen DJ (1992) Self-and cross-fertilization in plants. I. Functional dimensions. Int $\mathrm{J}$ Plant Sci 153:358-369. https://doi.org/10.1086/297040

Mesquita-Neto JN, Vieira ALC, Schlindwein C (2021) Minimum size threshold of visiting bees of a buzz-pollinated plant species: consequences for pollination efficiency. Am J Bot 118:1006-1015. https://doi.org/10.1002/ajb2.1681

Michener CD (2007) The bees of the world, 2nd edn. The Johns Hopkins University Press, Baltimore

Morais JM, Consolaro HN, Bergamini LL, Ferrero V (2020) Patterns of pollen flow in monomorphic enantiostylous species: the importance of floral morphology and pollinators' size. Plant Syst Evol 306:1-12. https://doi.org/10. 1007/s00606-020-01627-1

Moure JS, Melo GAR, Vivallo F (2007) Centridini Cockerell and Cockerell, 1901. Catalogue of bees (Hymenoptera, Apoidea) in the Neotropical Region. Sociedade Brasileira de Entomologia, Curitiba, pp 83-142

Múlgura de Romero ME (2005) Malpighiaceae. In: Burkart AE, Bacigalupo NM (eds) Flora Ilustrada de Entre Ríos (Argentina): dicotiledóneas arquiclamídeas. Geraniales a Umbeliflorales. Instituto Nacional de Tecnología Agropecuaria, Secretaría de Agricultura, Ganadería Pesca y Alimentos, Buenos Aires, pp 71-86

Ne'eman G, Jürgens A, Newstrom-Lloyd L, Potts SG, Dafni A (2010) A framework for comparing pollinator performance: effectiveness and efficiency. Biol Rev 85:435-451. https://doi.org/10.1111/j.1469-185X.2009.00108.x

Ollerton J (1996) Reconciling ecological processes with phylogenetic patterns: the apparent paradox of plant-pollinator systems. J Ecol 84:767-769

Ollerton J, Watts S (2000) Phenotype space and floral typology: towards an objective assessment of pollination syndromes. Det Norske Videnskaps-Akademi I Matematisk, Ny Serie 39:149-159

Potts SG, Dafni A, Ne'emanan G (2001) Pollination of a core flowering shrub species in Mediterranean phrygana: variation in pollinator diversity, abundance and effectiveness in response to fire. Oikos 92:71-80. https://doi.org/10. 1034/j.1600-0706.2001.920109.x

R Development Core Team (2013) R: a language and environment for statistical computing. R Foundation for Statistical Computing. https://www.r-project.org/. Accessed 11 Feb 2021 
Roig Alsina A (2000) Claves para las especies argentinas de Centris (Hymenoptera, Apidae), con descripción de nuevas especies y notas sobre distribución. Rev Mus Argentino Cienc Nat 2:171-193

Sazan MS, Bezerra ADM, Freitas BM (2014) Oil collecting bees and Byrsonima cydoniifolia A. Juss. (Malpighiaceae) interactions: the prevalence of long-distance cross pollination driving reproductive success. An Acad Bras Ciênc 86:347-358. https://doi.org/10.1590/00013765201420130049

Sazima M, Sazima I (1989) Oil-gathering bees visit flowers of eglandular morphs of the oil-producing Malpighiaceae. Bot Acta 102:106-111. https://doi.org/10.1111/j.14388677.1989.tb00073.x

Schemske DW, Horvitz CC (1984) Variation among floral visitors in pollination ability: a precondition for mutualism specialization. Science 225:519-521. https://doi.org/10. 1126/science.225.4661.519

Schneider CA, Rasband WS, Eliceiri KW (2012) NIH Image to ImageJ: 25 years of image analysis. Nat Methods 9:671-675

Shorthouse DP (2010) SimpleMappr, an online tool to produce publication-quality point maps. https://www.simplemappr. net/. Accessed 16 Apr 2021

Sigrist MR, Sazima M (2004) Pollination and reproductive biology of twelve species of neotropical Malpighiaceae: stigma morphology and its implications for the breeding system. Ann Bot 94:33-41. https://doi.org/10.1093/aob/ mch108

Simpson BB, Neff JL (1981) Floral rewards: alternatives to pollen and nectar. Ann Missouri Bot Gard. 68:301-322. https://doi.org/10.2307/2398800

Stebbins GL (1970) Adaptive radiation of reproductive characteristics in angiosperms, I: pollination mechanisms. Annu Rev Ecol Syst 1:307-326. https://doi.org/10.1146/ annurev.es.01.110170.001515
Stout JC (2000) Does size matter? Bumblebee behaviour and the pollination of Cytisus scoparius L. (Fabaceae). Apidologie 31:129-139. https://doi.org/10.1051/apido:2000111

Torretta JP, Aliscioni SS, González-Arzac A, Avalos AA (2017) Is the variation of floral elaiophore size in two species of Stigmaphyllon (Malpighiaceae) dependent on interaction with pollinators? Plant Ecol Divers 10:403-418. https:// doi.org/10.1080/17550874.2018.1434567

Traveset A, Sáez E (1997) Pollination of Euphorbia dendroides by lizards and insects: spatio-temporal variation in patterns of flower visitation. Oecologia 111:241-248

Vilas Boas JC, Fava WS, Laroca S, Sigrist MR (2013) Two sympatric Byrsonima species (Malpighiaceae) differ in phenological and reproductive patterns. Flora 208:360-369. https://doi.org/10.1016/j.flora.2013.05.003

Vinson SB, Frankie GW, Williams HJ (1996) Chemical ecology of bees of the genus Centris (Hymenoptera: Apidae). Fla Entomol. 79:109-129. https://doi.org/10.2307/3495809

Vogel S (1974) Ö lblumen und olsammelnde Bienen. Trop Subtrop Pflanzenwelt 7:1-267

Vogel S (1990) History of the Malpighiaceae in the light of pollination ecology. Mem N Y Bot Gard 55:130-142

Wilson P, Thomson JD (1991) Heterogeneity among floral visitors leads to discordance between removal and deposition of pollen. Ecology 72:1503-1507. https://doi.org/10. 2307/1941124

Young HJ, Stanton ML (1990) Influences of floral variation on pollen removal and seed production in wild radish. Ecology 71:536-547. https://doi.org/10.2307/1940307

Publisher's Note Springer Nature remains neutral with regard to jurisdictional claims in published maps and institutional affiliations. 